\title{
Crops, Livestock, and COVID-19, Oh My: An Overview Of Potential Covid-19 Liability In Agricultural Operations
}

\author{
Paul Goeringer \\ University of Maryland-College Park, Igoering@umd.edu \\ Julie Walker \\ julie.walker@drake.edu
}

Follow this and additional works at: https://scholarship.law.tamu.edu/lawreview

Part of the Agriculture Commons, and the Business Commons

\section{Recommended Citation}

Paul Goeringer \& Julie Walker, Crops, Livestock, and COVID-19, Oh My: An Overview Of Potential Covid-19 Liability In Agricultural Operations, 8 Tex. A\&M L. Rev. 677 (2021).

Available at: https://doi.org/10.37419/LR.V8.14.2

This Article is brought to you for free and open access by Texas A\&M Law Scholarship. It has been accepted for inclusion in Texas A\&M Law Review by an authorized editor of Texas A\&M Law Scholarship. For more information, please contact aretteen@law.tamu.edu. 
ARTICLES

\title{
CROPS, LIVESTOCK, AND COVID-19, OH MY: AN OVERVIEW OF POTENTIAL COVID-19 LIABILITY IN AGRICULTURAL OPERATIONS
}

\author{
by: Paul Goeringer* and Julie Walker**
}

TABLe of Contents

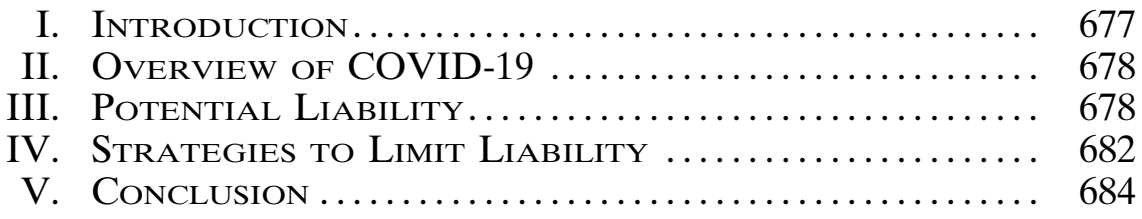

\section{INTRODUCTION}

The year 2020 presented a new potential risk of which many business owners, including agricultural operators, were unaware: a global pandemic related to the SARS-CoV-2 virus, also known as COVID19. Starting in March 2020, the United States worked to contain this virus, while businesses sought to protect their workers (who had to continue working to work) as well as their customers. ${ }^{1}$ At the same time, a number of businesses had concerns about how to limit liability from customers arguing later that the business had spread the virus. ${ }^{2}$

This Article explores the potential liability agricultural operations face and ways to manage the risks associated with COVID-19. Part II looks at what the virus is. Part III explores potential liability, and Part

DOI: https://doi.org/10.37419/LR.V8.I4.2

* Senior Faculty Specialist and Extension Legal Specialist, Department of Agricultural and Resource Economics, College of Agriculture and Natural Resources, University of Maryland. All thoughts, opinions, and mistakes in the article reflect on the author and not the University of Maryland. La Cheeserie. The Authors would like to thank the staff at the Texas A\&M Law Review for the help in developing this Article and the invitation to present at the virtual symposium.

** Faculty Assistant Department of Agricultural and Resource Economics, College of Agriculture and Natural Resources, University of Maryland. She earned a Bachelor of Science in Sustainable Agriculture and Food Systems from the University of New Hampshire. She holds a Juris Doctor from Drake Law School.

1. Guidance for Businesses and Employers Responding to Coronavirus Disease 2019 (COVID-19), Ctrs. For Disease Control \& Prevention (Jan. 4, 2021), https://www.cdc.gov/coronavirus/2019-ncov/community/guidance-business-response.html [https://perma.cc/F3JR-LK7Q].

2. David Morgan, Corporate America Seeks Legal Protection for When Coronavirus Lockdowns Lift, Reuters (April 21, 2020, 5:19 AM), https:// www.reuters.com/article/us-health-coronavirus-usa-liability/corporate-america-seekslegal-protection-for-when-coronavirus-lockdowns-lift-idUSKCN223179 [https:// perma.cc/M6W4-3GM9]. 
IV details potential methods to manage and limit that liability. Part V concludes.

\section{Overview OF COVID-19}

COVID-19 predominantly spreads through direct contact or respiratory droplets. ${ }^{3}$ Contact transmission occurs when an individual touches a contaminated surface (also known as fomites) and then touches his or her mucus membranes. ${ }^{4}$

When an infected person coughs, sneezes, or talks, he or she expels respiratory droplets, which can travel short distances. ${ }^{5}$ In close-contact situations, larger droplets quickly fall out of the air and may directly land on another person. ${ }^{6}$ Conversely, smaller droplets have the potential to become aerosolized and remain floating in the air for minutes or even hours. ${ }^{7}$ In a poorly ventilated space, people may become infected by inhaling suspended, virus-laden particles. ${ }^{8}$

Experts believe large respiratory droplets are the main method of transmission for COVID-19, which makes masking an exceptionally effective tool to stem the spread of the virus. ${ }^{9}$

\section{Potential Liability}

As noted earlier, defining the potential liability businesses could face from COVID-19 will be challenging for courts. In any situation, a company is required to provide employees with a safe working environment. ${ }^{10}$ With COVID-19 specifically, this could include providing an employee with masks, gloves, temperature checks, and requiring social distancing at work. For businesses with customers, the liability standard would require the business to provide a reasonably safe environment and consider possible dangerous conditions that spread the virus. For a customer at a farm business, the owner may require masks, put up signage reminding customers to social distance, con-

3. How COVID-19 Spreads, Ctrs. For Disease Control \& Prevention, https://www.cdc.gov/coronavirus/2019-ncov/prevent-getting-sick/how-covidspreads.html (Oct. 28, 2020) [https://perma.cc/8PXL-3XU8].

4. Scientific Brief: SARS-CoV-2 and Potential Airborne Transmission, CTRs. For Disease Control \& Prevention, https://www.cdc.gov/coronavirus/2019-ncov/ more/scientific-brief-sars-cov-2.html\#: :text=contact \%20transmission \%20is\%20infection \%20spread, \%E2\%80\%9Cfomite \%20transmission.\%E2\%80\%9D (Oct. 5, 2020) [https://perma.cc/WX5L-DF7S].

5. Id.

6. Id.

7. $I d$.

8. Id.

9. Id.

10. Occupational Safety \& Health Admin., Employer Responsibilities, U.S. DeP'T LAB., https://www.osha.gov/as/opa/worker/employer-responsibility.html\#: $\sim$ :text $=$ under $\% 20$ the $\% 20$ OSH $\% 201$ law $\% 2 \mathrm{C} \% 20$ employers,issued $\% 20$ under \%20the \%20OSH\%20Act [https://perma.cc/ZM3K-WHD5]. 
sider ways to improve ventilation, and clean highly touched surfaces throughout the day, and other possible strategies.

Often, a business's potential liability can be addressed through a negligence action. Individuals have filed several actions claiming that businesses were negligent because they failed to follow reasonable safety precautions to prevent the spread of COVID-19.11

The general rule is that "a person who negligently exposes another to an infectious or contagious disease, which such other thereby contracts, is liable in damages." 12 State tort law will often lay out the elements of negligence in different ways, but typically, a plaintiff will need to demonstrate "a duty the defendant owes to the plaintiff, a breach of that duty by the defendant, a causal connection between the breach and the plaintiff's injury, and actual injury." 13

In the case of negligently exposing another to a disease, we often have to look at the diligence required to prevent exposure based on the nature and character of the disease. ${ }^{14}$ Looking at past decisions involving other disease outbreaks can provide us with a guidepost for how courts may handle disputes involving COVID-19.

The first prong of negligence requires a plaintiff to prove the defendant had knowledge of the presence of the disease for a duty to exist. ${ }^{15}$ For example, in Earle v. Kuklo, a tenant alleged her infant daughter contracted tuberculosis when her landlord failed to disclose that the landlord and her family were infected with tuberculosis. ${ }^{16}$ Due to the close proximity of the apartments (plaintiff rented a second-floor apartment from the landlord who lived on the first floor) and the highly communicable nature of the disease, the landlord should have assumed the premises were infected with a dangerous pathogen. ${ }^{17}$ The court found that, because the landlord knew tuberculosis was present, she had a duty to disclose the dangerous condition. ${ }^{18}$ This case highlights the knowledge element, which must be satisfied to hold a defendant negligent for transmitting a disease. ${ }^{19}$

Courts further specify that the defendant must have knowledge of the illness at the time of transmission in order to be held liable. ${ }^{20}$ In

11. Many of the initial cases filed involve the cruise industry. Complaint for: 1 . Negligence - Personal Injuries and Wrongful Death, 2. Survival Action at 18-20, MAA v. Carnival Corp., No. 2:20CV06341 (C.D. Cal. filed July 16, 2020); Dianoia's Eatery, LLC v. Motorists Mut. Ins. Co., No. 20-787, 2020 WL 5051459, at *3 (W.D. Pa. Aug. 27, 2020); Weissberger v. Princess Cruise Lines, Ltd., No. 2:20-cv-02267RGK-SK, 2020 WL 3977938, at *1-2 (C.D. Cal. July 14, 2020).

12. 39 Am. Jur. 2D Health $\S 101$ (2020).

13. 57A Ам. Jur. 2D Negligence $\$ 71$ (2020).

14. 39 Am. Jur. 2D Health $\$ 101$ (2020).

15. $I d$.

16. Earle v. Kuklo, 98 A.2d 107, 108 (N.J. Super. Ct. App. Div. 1953).

17. Id.

18. Id. at 109 .

19. Id.

20. Andrews v. MV Transp., 126 F. Supp. 3d 9, 12 (D.D.C. 2015). 
Andrews v. MV Transportation, plaintiffs alleged a bus driver was negligent because he continued working despite being infected with tuberculosis. ${ }^{21}$ This is distinguishable from Earle in that here, the driver was incorrectly diagnosed with bronchitis at the time of transmission, and there was no evidence to demonstrate he knew otherwise. ${ }^{22}$ The driver followed the doctor's recommended course of treatment for bronchitis and returned to work after his symptoms resolved, assuming he was cured. ${ }^{23}$ Ultimately, the court found the correct diagnosis did not annul the prior misdiagnosis, and thus the driver did not have the requisite knowledge to demonstrate negligent transmission of a disease. ${ }^{24}$

Beyond the knowledge element, an entity may assume a duty by caring for a sick individual. ${ }^{25}$ In Missouri, Kansas \& Texas Railway Co. of Texas v. Wood, a railroad was held responsible for potentially exposing others to smallpox when an employee became infected. ${ }^{26}$ The employee contracted smallpox at a railroad-owned hospital, which discharged him before he developed symptoms. ${ }^{27}$ When the infection became apparent, the railroad assumed care of the employee by placing him in a quarantine camp and hiring a guard to care for him. ${ }^{28}$ The nurse, however, failed to adequately monitor the employee, which allowed him to escape while delirious and consequently expose the plaintiff. ${ }^{29}$ In finding the defendant liable, the Supreme Court of Texas pointed to English common law that "there is a legal obligation on the sick person and on those who have the custody of him not to do anything that can be avoided which shall tend to spread the infection." ${ }^{30}$ Because the railroad was aware of the infection and took responsibility for the infected employee's care, it owed an affirmative duty to the public to prevent exposure by containing and supervising the employee. ${ }^{31}$ Thus, the railroad was liable for damages. ${ }^{32}$

Vicarious liability is also a concern for employers. Based on many of these prior court decisions, courts will consider an employer's knowledge of an ill employee when assessing whether the doctrine of

21. Id. at 11 .

22. Compare Andrews, 126 F. Supp. 3d at 12, with Earle v. Kuklo, 98 A.2d 107, 109 (N.J. Super. Ct. App. Div. 1953) (demonstrating that, in Earle, the landlord knew she and her family were infected).

23. Andrews, 126 F. Supp. 3d at 12.

24. Id.

25. Mo., K. \& T. Ry. Co. of Tex. v. Wood, 66 S.W. 449, 450 (Tex. 1902).

26. $I d$.

27. Id. at $449-50$.

28. Id. at 450 .

29. Id.

30. Id. at 451 (quoting Metro. Asylum Dist. Managers v. Hill (1881) 6 App. Cas. 193, 204 (U.K.)).

31. $I d$.

32. Id. 
respondeat superior will apply to the employer. ${ }^{33}$ Under this doctrine, an employer or principal may be liable for an employee's or agent's wrongful acts committed within the scope of the employment or agency. ${ }^{34}$ In terms of COVID-19, employer-provided testing may raise liability issues. If an employee tests positive and makes the employer aware of the positive test result, the employer now has actual knowledge and must take steps to mitigate the risk the sick employee poses to the workplace. Allowing a known COVID-19-positive employee to come to work would create liability issues for the agricultural operation. Recalling Andrews, if a worker negligently exposes others to a communicable disease while on the job, the employer may be liable for damages. ${ }^{35}$ In practice, employers should lessen the risk an infectious employee poses by requiring him or her to remain at home and self-isolate according to current health requirements.

But given COVID-19's nature, courts might look beyond an employer's knowledge of a sick employee. As discussed earlier, courts may not always look only at knowledge, but also at the diligence required to prevent exposure based on the nature and character of the disease, ${ }^{36}$ which could include implementing policies such as requiring masks and requiring employees to stay home when sick. These practices help demonstrate reasonable care to prevent spreading the virus and put the farm business on better footing in a potential lawsuit. ${ }^{37}$

Due to the nature of COVID-19 and the difficulty that can arise in proving fault, commentators have pointed out that plaintiffs' attorneys will not have strong incentives to bring claims against businesses. ${ }^{38}$ However, this is not to say that an employee could not sue an agricultural business taking no reasonable precautions to prevent the spread of COVID-19.

At the same time, if sued, an agricultural business could use potential defenses when following reasonable precautions to prevent the spread of COVID-19. For example, the agricultural business could potentially use the assumption of the risk defense. The assumption of the risk could be express or implied ${ }^{39}$ based on the idea that a plaintiff who voluntarily confronted a known risk should not later be allowed to hold a business liable for damages caused by exposure to that risk. ${ }^{40}$

33. 39 Aм. Jur. 2D Health $\S 101$ (2020).

34. Respondeat Superior, Black's Law Dictionary (11th ed. 2019).

35. Andrews v. MV Transp., 126 F. Supp. 3d 9, 11 (D.D.C. 2015).

36. 39 Am. Jur. 2D Health § 101 (2020).

37. Matthew Blaschke, Nicholas Howell \& Carol Wood, COVID-19 Return to Work Q\&A: Premises Liability Issues, JDSuprA (May 22, 2020), https:// www.jdsupra.com/legalnews/covid-19-return-to-work-q-a-premises-29302/ [https:// perma.cc/BZ7F-L8YZ].

38. Betsy J. Grey \& Samantha Orwoll, Tort Immunity in the Pandemic, 96 InD. L.J. SupPlEMENT 66, 84 (2020).

39. See id.

40. 57B Ам. Jur. 2D Negligence $§ 759$ (2020). 
Because a customer could understand the potential risks of contracting the virus but voluntarily confronts those risks by frequenting a business, that customer may have assumed the risk and cannot hold a business liable for negligence. ${ }^{41}$ Meanwhile, using waivers where a customer expressly acknowledges the risks of contracting the virus and the customer is willingly undertaking the risk may or may not hold up in court for various reasons, including arguments that such waivers are against public policy. ${ }^{42}$

Congress and state legislatures may also provide additional lawsuit protections by enacting immunity protections. ${ }^{43}$ These laws will vary from state to state and be worth examining as another potential limitation to an employer's liability. For example, in Georgia, a business with the appropriate signage imposes a rebuttable presumption of assumption of the risk by a customer. ${ }^{44}$ At this point, Texas, as another example, does not have a similar statute, and one was not introduced in the most recent legislative session. ${ }^{45}$

Regardless of whether a state has enacted legislation to limit liability from COVID-19 exposure, an agricultural business should consider continuing reasonably safe business practices by requiring masks, providing signage to remind customers to maintain social distance, considering ways to improve ventilation, and improving cleaning of highly touched surfaces throughout the day.

\section{Strategies to Limit Liability}

As discussed, the best strategy to manage risks associated with possible lawsuits from COVID-19 is to be proactive. The following discussion includes thoughts on what an agricultural business owner specifically could be doing to demonstrate maintaining a reasonably safe business environment.

First, agricultural business owners should stay informed on the instructions of national and state health officials. Information will continue changing as we learn more about the virus and how it impacts certain segments of the population. Although information is constantly changing, staying informed will allow agricultural business owners to utilize the latest strategies. Changing information is frustrating, but recognize that it is a good thing and means we are learning more about the virus and how to stay safe. Keeping abreast of these

41. Grey \& Orwoll, supra note 38 , at 84 .

42. Id. at 85 .

43. COVID-19 Survey of State Liability Reform, KING \& Spalding, https:// www.kslaw.com/pages/covid-19-survey-of-state-liability-reform [https://perma.cc/ T4RL-R5YB].

44. Ga. Code Ann. § 51-16-3 (West, Westlaw through 2020 Leg. Sess.).

45. Lowell Pearson et al., 50-State Update on COVID-19 Business Liability Protections, HusCH BlACKwEll, https://www.huschblackwell.com/newsandinsights/50state-update-on-covid-19-business-liability-protections (Mar. 18, 2021) [https:// perma.cc/M2ML-TDBK]. 
changes will allow agricultural business owners to incorporate the latest safety precautions into their operations and may assist in any potential legal claims.

Second, agricultural business owners should realize resources exist to help them stay up-to-date on the latest information related to the virus. For example, the $\mathrm{CDC}$ has resources to assist businesses with reopening and staying open during the pandemic, ${ }^{46}$ including guidance for preparing workplaces for COVID-19, frequently asked questions, and more. Businesses should check with their state department of agriculture to determine if additional information has been developed for agricultural operations where they operate. The Maryland Department of Agriculture, for example, has developed guidance to assist agritourism and other agricultural businesses to stay open safely during the pandemic. ${ }^{47}$ The Texas Department of State Health Services has developed a few health and safety recommendations for a variety of businesses as well. ${ }^{48}$

Third, agricultural businesses should practice good communication with employees and customers on the safety practices they are following in their agricultural businesses. If masks are required while working or while inside the business, these businesses should ensure employees understand that and have access to the appropriate masks and any other necessary personal protective equipment. If safety practices change based on recommendations from health officials, businesses should communicate that change to their employees and customers.

The final thought on practicing good communication is that businesses should be models for the safety practices they want others to follow. If business owners require employees and customers to wear masks, they should do the same. Employees will more likely want to follow the rules if they see the boss doing so. ${ }^{49}$

Once businesses develop their strategies for handling COVID-19 and have communicated those policies to their employees, they should have employees sign documentation stating both that the employees understand the policy and how policy changes will be communicated

46. Workplaces and Businesses: Plan, Prepare, and Respond, CTRs. For DiseAse Control \& Prevention: COVID-19, https://www.cdc.gov/coronavirus/2019-ncov/ community/workplaces-businesses/index.html (Feb. 11, 2021) [https://perma.cc/FZ4S4779].

47. COVID-19, Md. DeP'T Agric. (Oct. 19, 2020), https://news.maryland.gov/ mda/category/covid-19/ [https://perma.cc/GMN3-FPEL].

48. Information for Businesses \& Employers, Tex. Dep't State Health Servs., https://www.dshs.texas.gov/coronavirus/business.aspx [https://perma.cc/L5NA-PH3Z].

49. 5 Ways to Lead by Example in the Workplace, Univ. Notre DAme, https:// www.notredameonline.com/resources/leadership-and-management/5-ways-to-leadby-example-in-the-workplace/\#: :text=5\%20Ways $\% 20$ to $\% 20$ Lead $\% 20$ by $\% 20$ Example,-Get $\% 20$ down $\% 20$ and\&text=listen $\% 20$ to $\% 20$ your $\% 20$ team $\% 20 \%$ E2\%80\% $93 \% 20$ With,say\%20and\%20who\%20is\%20listening (Oct. 9, 2020) [https://perma.cc/ RQB8-AX76]. 
to them. This will help demonstrate that businesses require employees to follow reasonable strategies to keep employees and customers safe during the pandemic. At the same time, businesses should develop disciplinary plans for what happens if someone messes up and does not follow the appropriate business safety requirements-and enforce that policy-even if it is the business owner or a family member not following those safety guidelines.

Businesses should consider adding extra signage around the agricultural business reminding employees and potential customers of the business policies set up during the pandemic. This will remind employees of the policies they agreed to earlier and help customers understand the strategies the business is following to keep them safe. This signage could include reminders that masks or face coverings must be worn at all times, to wash hands regularly, where sanitization stations - if any-are located, and reminders to social distance. As mentioned earlier, if customers do not want to follow this signage, businesses should consider options to enforce the policy against them that work for their operation, from verbally asking them to follow the rules to asking them to leave the premises.

Finally, if businesses have not done so already, they should talk to their insurance carriers, general liability provider, or even their workers' compensation provider. Discussions with these insurance providers can help businesses understand what their existing policies will cover and any additional strategies they might suggest to limit a business's liability.

\section{CONClusion}

Plaintiffs may have difficulty proving a business's liability in cases related to COVID-19. Given this, it is still important to realize that doing nothing in the operation is not a strategy if faced with a lawsuit. Businesses should take the time to consider what their operation needs and develop strategies that will work for them. They should keep on top of the latest information about safety precautions to consider. They should communicate any practices to their employees and customers. Additionally, they should communicate with insurance providers to determine additional strategies they may want to incorporate into the operation.

None of us planned to go through a global pandemic, nor is this something many of us were prepared to handle a year ago, but taking the time to develop a strategy now will help prevent lawsuits down the road. 